\title{
Mediterranean diet, culture and heritage: challenges for a new conception
}

\author{
F Xavier Medina*
}

Food Systems, Culture and Society, Open University of Catalonia (UOC), Rambla del Poblenou, 156, 08038

Barcelona, Spain, International Commission on the Anthropology of Food (ICAF), Barcelona, Spain

Submitted 8 December 2008: Accepted 4 April 2009

\begin{abstract}
The aim of the present article is to discuss the role of the Mediterranean diet as a part of Human Culture and Intangible Cultural Heritage. Until the present, Mediterranean diet has been observed as a healthy model of medical behaviour. After its proposal as a Cultural Heritage of the Humanity at UNESCO (United Nations Educational, Scientific and Cultural Organization), Mediterranean diet is actually being observed as a part of Mediterranean culture and starting its concept as an equivalent of Mediterranean Cultural Food System or Mediterranean Culinary System. At the candidacy of Mediterranean diet as a World Cultural Intangible Heritage to be presented at UNESCO in 2008, this new conception is making sense. A new point of view that will be capital in the future discussions about the Mediterranean diet, their challenges and their future perspectives.
\end{abstract}

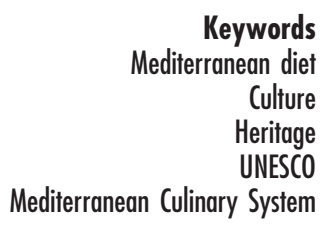

Since 1999 (with the international distinction of the UNESCO (United Nations Educational, Scientific and Cultural Organization) Proclamation of Masterpieces of the Oral and Intangible Heritage of Humanity) and later in 2001, with the declaration by UNESCO, for the first time, of nineteen spaces of Intangible Heritage of Humanity, we can consider that the 'official' concept of heritage has in some way started to dematerialise by UNESCO and has recognised fields that are beyond the merely monumental and environmental, thereby widening its field towards more ethnoanthropological and less tangible aspects. $\dagger$ To date (June 2008), ninety-five States Parties members of UNESCO have ratified the Convention. Others have announced their intention to do so very soon ${ }^{(1)}$.

\section{Starting the way for food as Cultural Intangible Heritage}

An important aspect that we wish to emphasise here is that gastronomic heritage, and, by extension, human food in general, is (or should be) included within this emergent immaterial heritage. If UNESCO's 2005 declaration of

$\dagger$ However, it should be noted that the Material Heritage declarations are well above 700 , while those of Masterpieces of the Intangible Cultural Heritage of Humanity were, after 2005, just ninety. For further information on this issue, consult: http://www.unesco.org/culture/intangible-heritage/

\$ See the 'Convention for the Safeguarding of the Intangible Cultural Heritage: Second Session of the General Assembly', Paris, UNESCO, June 2008. http://portal.unesco.org/culture/es/ev.php-URL_ID =37468\&URL_DO=DO_ TOPIC\&URL_SECTION=201.html (accessed June 2008). assets has had an outstanding characteristic - of course, from the point of view that we want to emphasise here it is that, for the first time, a country like Mexico has presented its culinary art and gastronomy with the aim of being declared 'Heritage of Humanity'.

The importance of this Mexican initiative, particularly, is that they have opened the cultural intangible field to the possibility of obtaining a declaration from UNESCO ${ }^{(2)}$. However, as Moncusí and Santamarina ${ }^{(3)}$ note, the reasons for its non-inclusion by UNESCO respond to an important series of problems related to its candidature, that is, 'Mexican cuisine does not fit the characteristics of what is recognised as a Masterpiece of the Oral and Immaterial Heritage of Humanity, as its risk of disappearance is not clear; its frame of reference is too wide (State Nation), and it does not place the asset in question within a specific space-time framework (festival, ceremony, ritual, theatre performance context or similar).'

But it is true that, both before and after, different initiatives and candidatures related with the food sector have been submitted (or are in process of submission) to UNESCO, but with different characteristics and regarding different categories (particularly as cultural landscapes or cultural routes). These include the jurisdiction and landscape of the Saint-Émilion vineyards in France (1999); the wine region of Alto Douro (2001) and the grape and wine-growing landscape of Pico Island in Portugal (2004); the Agavero landscape and the old tequila industry in Mexico (2006); or - especially relevant in terms of the Mediterranean area - the Cultural Route of the Vine and 
Wine in the Towns of the Mediterranean, ${ }^{*}$ which is currently in the indicative list of Spanish candidaturest (submitted from the Spanish Autonomous Regional Community of La Rioja) awaiting its future consideration.

\section{Following (or starting) the Mediterranean way}

This latter example (the Cultural Route of the Vine and Wine in the Towns of the Mediterranean) places us in the Mediterranean area seen (in heritage terms) from different perspectives: especially as an 'area of culture' (even as the 'cradle of culture'), with all the ideological significance that this involves, also as a transnational area, beyond political borders, and therefore as an area of creation and promotion of 'product'.

In this same context, Mediterranean diet is another initiative that has tried to launch some agreement for the processing of its application to UNESCO: the proposal for the declaration of the Mediterranean diet as Intangible Heritage of Humanity developed by a multinational joint effort by Spain, Italy, Greece and Morocco, and under the general technical coordination of the Mediterranean diet Foundation.

As a precedent, and between 29 September and 1 October 2005, Rome hosted the 3rd Euro-Mediterranean Forum 'Dialogues between Civilizations and Peoples of the Mediterranean. The Food Cultures'. One of the proposals of the organisation included a specific roundtable with UNESCO members on the possible recognition of the Mediterranean diet as heritage, which finally came about in an academic session on the strategic need for a position of consensus on the Mediterranean diet, understood, in this case, as an innovative form in relation to this concept: beyond a medical diet, as a cultural system.\$

One of the problems in relation to this sought consensus came, in fact, from defining the Mediterranean diet itself ${ }^{(6)}$, with a certain division of views on this issue: while some of the participant speakers advocated defining it as 'traditional Mediterranean diet', others refused to include the term 'traditional' in its definition, without ever arguing the importance of the health actions and policies in this sense, but clarifying its recent history as a constructed medical concept and with a particular history in relation to cardiovascular illnesses and with the health of the population in general. As the general coordinator of this meeting (and also member of the Italian team responsible for the redaction of the candidacy), Sandro Dernini ${ }^{(7)}$, points:

The Mediterranean diet as a whole life style makes visible our cultural identity and diversity, providing

\footnotetext{
* In a previous article ${ }^{(4)}$ I devoted a brief analysis to this candidature in its Mediterranean context.

$\dagger$ See on this: http://www.mcu.es/jsp/plantillaAncho_wai.jsp?id=79\&area $=$ patrimonio\&contenido $=/$ patrimonio/pei/ph/phe/listCandidaturasEsp.html

* Another of the sessions was devoted to the erosion of the Mediterranean food inheritance, with which we introduced another of the factors that come into play when defining a world heritage declaration: the danger of disappearing ${ }^{(5)}$
}

a direct measure of the vitality of the culture in which is embedded. The Mediterranean diet is an expression of a Mediterranean style of life in continued evolution throughout time. Mediterranean diet as intangible cultural heritage is transmitted from generation to generation, and it is constantly recreated by communities and groups in response to the change of their environment and their history. It provides a sense of identity and continuity for the Mediterranean people.

At the present moment, the candidature of the Mediterranean diet to UNESCO is waiting for the final resolution at UNESCO (September 2009), always defined in strictly cultural (from an anthropological/ethnological point of view) and cultural heritage terms (including, among others, their scientific and health dimensions ${ }^{(8)}$. One of the problems of this candidature - beyond conceptual discussions - is that its frame of reference is really wide (a very big transnational region, four countries commanding the candidature, more than twenty countries involved, etc.), and also that it is not placed within a specific space-time framework (festival, ceremony, ritual, performance, etc., but including many of these items in a particular framework). In this sense, UNESCO must build a conceptual corpus and basic characteristics to evaluate not only the Mediterranean diet candidature but also many others that are already prepared or are in course.

\section{Other food initiatives}

In the last 4 months of 2006 came the submission of the presentation of a preliminary candidature dossier of French gastronomy as Heritage of Humanity, promoted by the Institut Européen d'Histoire et Cultures de l'Alimentation (IEHCA) and the Université François Rabelais in Tours. France (through its Ministry of Culture) plans to submit this candidature in 2009, with the aim of "Not "fixing" French cuisine or maintaining it in the mists of a glorious past but rather promoting its creativity and diversity, real signs of French cultural identity.' JeanRobert Pitte, ancient Rector of the Sorbonne University, has been charged by the French President, Nicolas Sarkozy, for the direction of this French candidacy*.

At the same time, Peru is also concluding its own dossier (by the National Institute of Culture), and other different initiatives are considering the possibility of presentation of their candidatures for its World Cultural Intangible Heritage recognition. Even Mexico is reconsidering the presentation of the Mexican Culinary System as intangible cultural heritage to UNESCO and, in this sense, they are organising an international technical meeting about culinary candidatures in Campeche City (Gulf of Mexico) in July 2008.

\footnotetext{
* Cf. the official information at the French Sénat website: http://
} www.ump-senat.fr/Gastronomie-francaise-au.html 


\section{Conclusion}

One of the most important points inside the candidatures is the development of one intensive and extensive plan and strategy of preservation, including necessary measures to ensure the safeguarding of the diversity of the Mediterranean food cultures heritage as a critical base for the safeguarding of the Mediterranean diet, understood as a cultural system. As Dernini (op. cit.) argues, these safeguarding measures should have internal and external coherence and provide a permanent trans-sector and inter-cultural channel of open dialogue through which Mediterranean diet's benefit should mutually be shared by all people living in the Mediterranean region. It should foster scientific and artistic studies and researches for an effective safeguarding of the Mediterranean diet as an intangible cultural heritage.

This preservation strategy should strengthen education initiatives, awareness-raising and capacity-building projects and training in the management of the intangible cultural heritage, in order to effectively preserve and to advance the transmission of Mediterranean diet heritage through the present difficult time into the future.

If anything is certain, it is that new candidatures (including Mediterranean diet) should learn as much as possible from the failure of Mexican cuisine's attempted accession to world intangible heritage. Any candidature mainly needs internal cultural coherence and consensus on it, and both elements are not as easy to achieve, as we might believe at first sight.

What is clear is that intangible heritage, and, within its field, gastronomic and food heritage, is in a moment of expansion, of recognition and awareness of its protection.
In this context, the different cultures of the Mediterranean region will undoubtedly have a lot to say.

\section{References}

1. The Convention for the Safeguarding of the Intangible Cultural Heritage (2009). http://www.unesco.org/culture/ ich/index.php?pg $=00006$

2. Medina FX (2007) Food heritage in the Mediterranean area: in search of new perspectives of promotion and interpretation. In Quaderns de la Mediterrània, 8, pp. 195-198. Barcelona: IEMed.

3. Moncusí A \& Santamarina B (2008) Bueno para comer, bueno para patrimonializar. La propuesta de la cocina mexicana como patrimonio inmaterial de la humanidad. In Patrimonio cultural y alimentación entre América $y$ Europa, pp. 127-142 [M Álvarez and FX Medina, editors]. Barcelona: Icaria.

4. Medina FX (2000) Alimentación mediterránea, patrimonio y tradición. Una visión desde la antropología. In Nueva antropología de las sociedades mediterráneas. Viejas culturas, nuevas visions, pp. 275-289 [MA Roque, editor]. Barcelona: Icaria.

5. The 2005 Rome Call for a Common Action on Food in the Mediterranean (2006). http://www.ciiscam.org/materiali/ 02-PDF\%20final\%20Document $\% 20$ Rome $\% 20$ Call $\% 202005$.pdf

6. Contreras J, Riera A \& Medina FX (editors) (2005) Sabores del Mediterráneo. Aportaciones para la promoción de un patrimonio alimentario común. Barcelona: IEMed.

7. Dernini S (2008) The strategic proposal to candidate the Mediterranean diet for inscription in the UNESCO List of Intangible Cultural Heritage. In Med.2008. Mediterranean Yearbook. 2007 in the Euro-Mediterranean Space. Barcelona: European Institute of the Mediterranean and Fundació CIDOB.

8. González Turmo I \& Mataix J (2009) La alimentación y la dieta mediterránea, patrimonio cultural inmaterial. Sevilla, Consejería de Agricultura, Junta de Andalucía. 